\title{
KEBIJAKAN PENILAIAN KINERJA DOSEN DI PROGRAM PASCASARJANA UNIVERSITAS NEGERI JAKARTA
}

\author{
Dwi Deswary*
}

\begin{abstract}
This research aimed to know about the implementation of performance appraisal policy lecturer in the graduate program and the impact of policy implementation in the learning performance. data sources obtained from the director of PPs, Assistant Director I and II, Ka.Prodi, Sekprodi and lecturer at PPS UNJ. Data collected by observation, interview and documentation. Data is analyzed using descriptive approach. Research findings to inform you that the performance measurement needs to articulate the vision/mission, organizational goals, and objectives of the organization. Strategies for achieving goals through lecture attendance and dissemination of instruments to students. for the development of measurement systems, the leading commitee have prepared the lecturer performance assessment instruments and processing for field assessment instrument is being done to report the results to the lecturers. Whereas for use of performance measurement information needs to be followed up to make it more effective. In addition to improving performance is highly depend on individual commitment each lecturer.
\end{abstract}

Keywords: Policy, assessment of lecturer performance.

\section{PENDAHULUAN}

Kualitas layanan sebagai salah satu indikator kinerja Sumber Daya Manusia (SDM) sering menjadi bahan kajian baik di kalangan mahasiswa sebagai pelanggan eksternal maupun di kalangan para dosen sebagai pelanggan internal. Meskipun persepsi mereka berbeda di dalam mendeskripsikan kinerja SDM khususnya para dosen yang ada di UNJ. Namun pada dasarnya memiliki satu arah yaitu tingkat kepuasan yang masih memerlukan pembenahan segera. Suatu kebijakan yang digulirkan pada umumnya dijadikan sebagai pedoman untuk bertindak sehingga mengarah pada pencapaian tujuan atau sasaran yang diinginkan. Demikian halnya dengan kebijakan penilaian kinerja dosen yang khususnya diarahkan pada kinerja pembelajaran.

Kebijakan penilaian kinerja dosen ini diarahkan pada pencapaian kepuasan pelanggan eksternal yaitu para mahasiswa sehingga perilaku berkarya sebagai wujud kualitas dosen dapat dirasakan oleh para stakeholders. Kepuasan pelanggan adalah tingkat perasaan seseorang setelah membandingkan kinerja atau hasil yang ia rasakan dibandingkan dengan harapannya. Ukuran kepuasan pelanggan memberikan umpan balik mengenai seberapa baik suatu lembaga/organisasi melaksanakan aktivitasnya. Untuk mewujudkan dan mempertahankan kepuasan pelanggan, organisasi harus melakukan empat hal. Pertama, mengidentifikasi siapa pelanggannya. Kedua, memahami tingkat harapan pelanggan atas kualitas. Ketiga, memahami strategi kualitas layanan pelanggan. Keempat, memahami siklus pengukuran dan umpan balik dari kepuasan pelanggan. Dengan demikian menurut Schnaars dalam Fandy Tjiptono (2003:134) kepuasan pelanggan merupakan strategi jangka panjang yang membutuhkan komitmen, baik menyangkut dana maupun sumber daya manusia. Untuk mencapai kepuasan pelanggan ini diperlukan indikator kinerja yang jelas sehingga arah pencapaian sasaran organisasi semakin jelas. Dari penjelasan yang telah dipaparkan,

\footnotetext{
* Dosen Program Pascasarjana Universitas Negeri Jakarta (Gd. M Kampus UNJ Jl. Rawamangun Muka, Jakarta Timur)
} 
penting dilakukan pengkajian tentang "Kebijakan Penilaian Kinerja Dosen di Program Pascasarjana Universitas Negeri Jakarta".

\section{Kebijakan.}

Dalam tulisan Solichin (1991:13) Carl Friedrich menyatakan bahwa kebijakan merupakan suatu tindakan yang mengarah pada tujuan yang diusulkan oleh seseorang, kelompok atau pemerintah dalam lingkungan tertentu sehubungan dengan adanya hambatan-hambatan tertentu seraya mencari peluang-peluang untuk mencapai tujuan atau mewujudkan sasaran yang diinginkan. Sedangkan Anderson dalam tulisan yang sama (1991:13) merumuskan kebijakan sebagai langkah tindakan yang secara sengaja dilakukan oleh seorang aktor atau sejumlah aktor berkenaan dengan adanya masalah atau persoalan tertentu yang dihadapi. Samodra Wibawa (1994:5) menjelaskan bahwa isi suatu kebijakan dapat bersifat pengulangan terhadap keterlaksanaan yang pernah dibuat, dapat pula bersifat radikal. Kebijakan dengan sifat kedua ini berarti bahwa kebijakan tersebut dibuat secara mendasar dengan pertimbangan yang rasional. Berbagai model kebijakan diuraikan berikut ini: (1) model elite, yaitu merupakan abstraksi dari suatu proses pembuatan kebijakan di mana kebijakan boleh dikatakan identik dengan perspektif elite politik, (2) model kelompok, yaitu merupakan abstraksi dari proses pembuatan kebijakan yang didalamnya beberapa kelompok kepentingan berusaha untuk mempengaruhi isi dan bentuk kebijakan secara interaktif, (3) model rasional, yaitu berasal dari pemikiran Herbert Simon tentang perilaku administrasi. Simon menekankan bahwa inti dari perilaku administrasi adalah proses pengambilan keputusan secara rasional. Model ini menekankan pada aspek efisiensi maupun ekonomis, karena perbandingan antara pengorbanan dan hasil yang dicapai harus bersifat rasional, (4) model inkremental, yaitu merupakan kritik terhadap model rasional. Kritik tersebut dilontarkan oleh Charles Lindblom yang mengatakan bahwa para pembuat kebijakan pada dasarnya tidak mau melakukan peninjauan secara ajeg terhadap seluruh kebijakan yang dibuatnya.

\section{Penilaian Kinerja}

Payaman J. Simanjuntak (2005:103) menjelaskan evaluasi/penilaian kinerja merupakan suatu metode dan proses penilaian pelaksanaan tugas (performance) seseorang atau sekelompok orang atau unit-unit kerja dalam suatu organisasi sesuai dengan standar kinerja atau tujuan yang ditetapkan lebih dahulu. Evaluasi/penilaian kinerja berarti memberi nilai atas pekerjaan yang dilakukan oleh seseorang dan untuk itu diberikan imbalan, kompensasi atau penghargaan. Evaluasi/penilaian kinerja merupakan cara yang paling adil dalam memberikan imbalan atau penghargaan kepada seseorang. Evaluasi/penilaian kinerja merupakan bagian dari fungsi manajemen yang penting yaitu evaluasi dan pengawasan.

Indikator kinerja dalam tulisan Akdon (2006:167) merupakan ukuran kuantitatif maupun kualitatif untuk menggambarkan tingkat pencapaian sasaran dan tujuan organisasi, baik pada tahap perencanaan, pelaksanaan maupun tahap pengendalian/setelah kegiatan selesai. Sedangkan syarat-syarat indikator kinerja

meliputi: spesifik dan jelas, dapat diukur secara objektif, menangani aspek-aspek yang relevan, harus penting/berguna untuk menunjukkan keberhasilan input, output, hasil/outome, manfaat maupun dampak serta proses, fleksibel dan sensitif terhadap perubahan pelaksanaan, efektif, dalam arti datanya mudah diperoleh, diolah, dianalisis dengan biaya yang tersedia. 
Penetapan indikator kinerja berdasarkan pada hasil perumusan perencanaan strategik yang meliputi tujuan, sasaran dan strategi organisasi. Lima macam indikator kinerja: 1) input (masukan), 2) output (keluaran), 3) outcome (hasil), 4) benefit (manfaat), dan impact (dampak). Standar kinerja merupakan ukuran tingkat kinerja yang diharapkan tercapai dan yang dinyatakan dalam suatu pernyataan kuantitatif. Penetapan standar kinerja dapat bersumber dari peraturan perundang-undangan yang berlaku, keputusan manajemen, pendapat para ahli, atau pengalaman dari pekerjaan yang sama tahun sebelumnya. Caranya dengan menggunakan metode DELPHI (menanyakan kepada pihak-pihak yang memiliki pengalaman dalam bidangnya).

Persyaratan standar kinerja yang harus dipenuhi terdiri atas: Dapat dicapai dalam kondisi yang ada, ekonomis, mudah diterapkan, mudah dimengerti, terukur, stabil dalam kurun waktu yang cukup lama, dapat diadaptasi dalam berbagai keadaan, legitimasi, didukung ketentuan/peraturan yang berlaku, fokus pada pelanggan, dapat diterima sebagai ukuran pembanding oleh pihak-pihak terkait. Pengumpulan data kinerja dilakukan dengan: 1) pengumpulan data dilaksanakan melalui pengamatan, survey, wawancara, dsb. 2) tujuan untuk memperoleh informasi kemajuan dari masingmasing indikator kinerja, meliputi: efektifitas, efisiensi, ketepatan waktu, akuntabilitas, integritas pelaksanaan program yang dirumuskan dalam perencanaan strategik.

Pengukuran kinerja dalam sistem manajemen kinerja menurut Vincent (2006:212) merupakan alat manajemen untuk menilai keberhasilan maupun kegagalan pelaksanaan strategi untuk mencapai tujuan dan sasaran organisasi. Pengukuran kinerja perlu diartikulasikan dengan: 1) visi/misi organisasi, 2) tujuan organisasi, 3) sasaran organisasi. Pengukuran kinerja meliputi penetapan indikator kinerja dan penentuan hasil capaian indikator kinerja. Unsur-unsur kunci pengukuran kinerja terdiri atas: 1) perencanaan yang menetapkan tujuan, sasaran dan strategi pencapaian tujuan, 2) pengembangan sistem pengukuran yang relevan, 3) penggunaan informasi, 4) pelaporan hasil secara formal.

Cara pengukuran kinerja yaitu dengan membandingkan kinerja nyata dengan kinerja yang direncanakan, membandingkan kinerja nyata dengan hasil (sasaran) yang diharapkan, membandingkan kinerja tahun ini dengan tahun-tahun sebelumnya, membandingkan kinerja dengan kinerja instansi lain, dan membandingkan kinerja nyata dengan standar. Metode pengukuran kinerja dapat dilakukan dengan langkahlangkah: (1) siapkan rencana kerja tahunan, (2) buat visi, misi, tujuan, sasaran yang cara penyampaiannya memuat kebijakan dan program satu tahun yang akan dikerjakan, (3) tentukan indikator kinerja kegiatan terdiri dari: a) indikator masukan, b) indikator proses, c) indikator keluaran, d) indikator hasil, e) indikator manfaat, f) indikator dampak.

Menurut Dale (2002:13), ukuran kinerja yang efektif terdiri dari ukuran kuantitatif, mudah difahami, seimbang, mudah dijangkau, dan dipublikasikan. Fokus evaluasi kinerja terdiri dari: evaluasi masukan, proses, keluaran, hasil, dan dampak. Keuntungan

dari evaluasi antara lain berupa berbaikan perencanaan, strategi, kebijakan, pengambilan keputusan, perbaikan masukan, proses, dan keluaran dan perbaikan tatanan/sistem prosedur. Evaluasi kinerja kegiatan dan sasaran dilakukan dengan pendekatan analisis input - proses - output dan pendekatan analisis input - output. Sedangkan evaluasi program dan kebijakan dilakukan dengan: (1) Evaluasi program dilakukan untuk mencari jawaban outcome, tahapannya: a) analisis logika program, b) desain evaluasi, c) penyusunan desain evaluasi, d) strategi pengumpulan dan analisis 
data. (2) Evaluasi kebijakan dilakukan sampai dampak yang terjadi, tahapannya: a) identifikasi masalah, b) perumusan masalah, c) perumusan alternatif, d) penyusunan kriteria, e) pemilihan alternatif, f) penyusunan rekomendasi kebijakan, g) rencana implementasi pelaksanaan kebijakan. (3) Strategi kunci keberhasilan pengukuran kinerja melibatkkan pimpinan. sense of urgency: a) komitmen pimppinan, b) keinginan organisasi untuk berkinerja tinggi, c) keinginan mengaitkan strategi organisasi dengan tujuan dan kegiatan organisasi, d) merupakan hasil dari program peningkatan kualitas organisasi, e) keselarasan dengan arah strategik.

Kerangka kerja konseptual yang dapat diterapkan untuk mengembangkan kinerja sebagai bagian dari proses manajemen harus berorientasi pada mutu. Manajemen mutu dalam implementasinya memerlukan komunikasi, keterlibatan anggota, dan perencanaan strategik yang breiorientasi pada pelanggan (SWOT). Manajemen atau pengelolaan mutu merupakan komponen integral dan tidak dapat dipisahkan dari proses pendidikan secara keseluruhan. Untuk itu perlu difahami fungsi-fungsi pokok manajemen mutu, yaitu perencanaan mutu, pengendalian mutu, dan peningkatan mutu.

Secara umum, perencanaan mutu merupakan proses yang sistematik dalam pengambilan keputusan tentang tindakan yang akan dilakukan pada waktu yang akan datang. Dalam perencanaan terkandung makna pemahaman terhadap apa yang telah dikerjakan, permasalahan yang dihadapi, alternatif pemecahannya, dan melaksanakan prioritas kegiatan yang telah ditentukan secara proporsional. Pengendalian mutu merupakan kegiatan untuk merealisasikan rencana menjadi tindakan nyata dalam rangka mencapai tujuan secara efektif dan efisien. Sedangkan peningkatan mutu dapat diartikan rangkaian upaya meningkatkan kinerja mutu ke tingkat yang tak pernah terjadi sebelumnya "terobosan". Pelaksanaan fungsi-fungsi manajemen mutu secara efisien dan efektif tersebut diarahkan pada peningkatan mutu pendidikan yang diharapkan.

Dengan demikian secara konseptual dalam penelitian ini yang dimaksud dengan kebijakan penilaian kinerja dosen adalah suatu tindakan yang mengarah pada suatu tujuan dengan menggunakan alat manajemen untuk menilai keberhasilan maupun kegagalan pelaksanaan strategi guna mencapai tujuan dan sasaran organisasi. Pengukuran kinerja diartikulasikan dengan visi/misi organisasi, tujuan organisasi, dan sasaran organisasi dengan pengukuran kinerja perencanaan yang menetapkan tujuan, sasaran dan strategi pencapaian tujuan, pengembangan sistem pengukuran yang releven, penggunaan informasi, dan pelaporan hasil secara formal.

\section{METODE}

Metode penelitian yang digunakan adalah metode deskriptif. Penelitian ini dilakukan di Program Pascasarjana Universitas Negeri Jakarta pada Tahun Ajaran

2009/2010. Adapun unit analisis yang digunakan adalah Direktur PPs, Asisten Direktur I dan II, dan Para Dosen di Program Pascasarjana Universitas Negeri Jakarta.

\section{HASIL DAN PEMBAHASAN}

Perlu ditegaskan bahwa dalam penilaian kinerja dosen perlu diperhatikan berbagai aspek seperti bagaimana visi dan misi dirumuskan, bagaimana tujuan dan sasaran juga ditetapkan dalam suatu program studi. Dari informasi yang diperoleh temuan penelitian menunjukkan bahwa perencanaan visi dan misi organisasi baik di dalam perumusannya melibatkan semua unsur terutama unsur pimpinan dan unit kerja 
yang ditunjuk ditambah unsur dosen untuk tingkat prodi. Kondisi ini sudah mencerminkan bahwa perencanaan perumusan visi dan misi yang dilakukan sudah memenuhi persyaratan tentang bagaimana sebenarnya visi dan misi harus dirumuskan. Demikian pula dalam penetapan tujuan, tampak bahwa aktivitas inipun dilakukan secara kolaboratif antara pimpinan dan unsur terkait dengan mengarah pada kebijakan yang lebih tinggi yaitu tingkat universitas. Dalam menetapkan tujuan lebih diarahkan pada upaya perbaikan kinerja pembelajaran melalui pemantauan terhadap kehadiran dosen. Sedangkan sasaran organisasi lebih ditekankan pada upaya memperbaiki komposisi staf dengan pengalaman, bakat, dan status; penerimaan dan promosi staf akademik dilakukan dengan asas kemanfaatan, moralitas, religius, kesesuaian dengan peraturan yang berlaku; diidentifikasikan secara sistematis sesuai dengan aspirasi individu dalam rangka kebutuhan individu dan kelembagaan; rasio dosen dengan mahasiswa diatur secara proporsional; kinerja dosen dievaluasi secara periodik berdasarkan daftar kehadiran; dosen diberi kesempatan untuk melakukan aktivitas untuk kepentingan pengembangan diri sesuai kebutuhan yang ada; dosen mampu mengidentifikasi kebutuhan untuk pengembangan lebih lanjut; mampu menggunakan berbagai metode pembelajaran, melakukan proses pembelajaran yang efektif sesuai kebutuhan; menggunakan media pembelajaran sesuai kebutuhan; teknik dan penilaian mahasiswa yang dikehendaki; dan dosen mampu memonitor kinerja pembelajarannya dengan memperhatikan visi, misi, tujuan dan sasaran lembaga, dengan demikian pengukuran terhadap kinerja dosen ini penting untuk dilakukan sesuai dengan pendapat Vincent (2006:212) yang mengatakan bahwa pengukuran kinerja merupakan alat manajemen untuk menilai keberhasilan maupun kegagalan strategis untuk mencapai tujuan dan sasaran organisasi.

Pengukuran kinerja perlu diartikulasi dengan visi/misi organisasi, tujuan organisasi, dan sasaran organisasi. Untuk strategi pencapaian tujuan, dilakukan dengan berbagai cara antara lain melalui absensi perkuliahan, sedangkan untuk pengembangan sistem pengukuran pimpinan beserta jajarannya yang perlu mempersiapkan instrumen penilaian kinerja dosen dalam pembelajaran dan mengolah hasil isian instrumen penilaiannya kemudian melaporkan hasilnya pada pihak yang berkepentingan. Pihak prodi harusnya ikut terlibat dalam penyusunan apalagi pengembangan instrumen yang digunakan tersebut termasuk pada aspek penilaiannya. Temuan ini sejalan dengan pendapat Carl Friedrich dalam tulisan Solichin (1991:13) yang menyatakan bahwa kebijakan merupakan suatu tindakan yang mengarah pada tujuan yang diusulkan oleh seseorang, kelompok atau pemerintah dalam lingkungan tertentu sehubungan dengan adanya hambatan-hambatan tertentu seraya mencari peluang-peluang untuk mencapai

tujuan atau mewujudkan sasaran yang diinginkan. Sedangkan Anderson dalam tulisan yang sama (1991:13) merumuskan kebijakan sebagai langkah tindakan yang secara sengaja dilakukan oleh seorang aktor atau sejumlah aktor berkenaan dengan adanya masalah atau persoalan tertentu yang dihadapi.

Untuk penggunaan informasi hasil pengukuran kinerja masih dianggap belum efektif untuk memperbaiki kinerja dosen dalam pembelajaran. Hal ini disebabkan antara lain masih dilihat dari daftar kehadiran dosen. Upaya untuk benar-benar mau memperbaiki kinerja tergantung pada komitmen masing-masing dosen, dan belum ada umpan balik yang diterapkan untuk bagaimana seharusnya memperbaiki kinerja dosen berdasarkan hasil pemantauan daftar kehadiran tersebut. Untuk aspek pelaporan hasil penilaian kinerja seharusnya hasil penilaian kinerja dosen yang dinilai oleh mahasiswa hasil pengolahannya langsung dilaporkan kepada dosen yang bersangkutan. Kondisi 
seperti ini tentu akan sangat menyulitkan ketika para pimpinan akan melakukan umpan balik dari hasil penilaian tersebut guna perbaikan kinerja dosen khususnya pada aspek pembelajaran yang diberikan.

Berbagai temuan penelitian seperti ini telah dijabarkan sesuai dengan pendapat Dale (2002:13) yang mengatakan bahwa di dalam pengukuran kinerja yang efektif fokus evaluasi kinerja terdiri dari: evaluasi masukan (input), proses (process), keluaran (output), hasil (outcome), dan dampak (impact). Keuntungan dari evaluasi antara lain berupa perbaikan perencanaan, strategi, kebijakan, pengambilan keputusan, perbaikan input, proses, dan output, dan perbaikan tatanan/ sistem prosedur. Dengan demikian, evaluasi kebijakan dilakukan sampai dampak (impact) yang terjadi. Untuk itu di dalam proses penilaian kinerja perlu strategi kunci keberhasilan pengukuran kinerja yang melibatkan pimpinan sense of urgency yang terjadi dari komitmen pimpinan, keinginan organisasi untuk berkinerja tinggi, keinginan mengaitkan strategi organisasi dengan tujuan dan kegiatan organisasi, merupakan hasil dari program peningkatan kualitas organisasi, dan keselarasan dengan arah strategik. Di samping itu kondisi ini didukung pendapat Herbert Simon dalam tulisan Samodra Wibawa (1994:10) tentang perilaku administrasi. Simon menekankan bahwa inti dari perilaku administrasi adalah proses pengambilan keputusan secara rasional. Model ini menekankan pada aspek efisiensi maupun ekonomis, karena perbandingan antara pengorbanan dan hasil yang dicapai harus bersifat rasional. Sepanjang kebijakan yang ditempuh akan memberikan suatu hasil yang baik dengan sumber daya yang paling sedikit, maka kebijakan tersebut layak untuk dilaksanakan.

\section{PENUTUP}

Kesimpulan. Pertama, Perencanaan visi dan misi organisasi melibatkan semua unsur terutama pimpinan dan unit kerja yang ditunjuk ditambah unsur dosen untuk tingkat prodi. Kedua, pengukuran kinerja perlu diartikulasikan dengan visi/misi organisasi, tujuan organisasi, dan sasaran organisasi. Ketiga, untuk pengembangan system pengukuran pihak pimpinanlah yang mempersiapkan instrumen penilaian kinerja dosen dalam pembelajaran dan mengolah hasil instrumen penilaiannya kemudian melaporkan hasilnya pada pihak dosen. Keempat, untuk penggunaan informasi hasil pengukuran kinerja dampaknya masih dianggap belum efektif untuk memperbaiki kinerja dosen dalam pembelajaran. Hal ini disebabkan: instrumen penilaian yang digunakan baru

pemantauan kehadiran dosen, sementara hasil pengisian kuesioner oleh mahasiswa belum diolah. Di samping itu, upaya untuk benar-benar mau memperbaiki kinerja sangat tergantung pada komitmen masing-masing dosen, dan belum ada umpan balik yang diharapkan untuk bagaimana seharusnya memperbaiki kinerja dosen berdasarkan hasil pemantauan kehadiran dan penilaian oleh mahasiswa. Kelima, untuk aspek pelaporan hasil penilaian kinerja dosen belum secara langsung dilaporkan kepada dosen yang bersangkutan. Jadi dosen belum mengetahui secara pasti bagaimana kondisi penilaian kinerjanya.

Saran. Dari hasil temuan penelitian, beberapa saran guna menunjang pembinaan kinerja dosen di Program Pascasarjana Universitas Negeri Jakarta dapat diuraikan sebagai berikut: Pertama, perlu ada balikan terhadap hasil penilaian kinerja dalam bidang pembelajaran secara terencana, transparan, dan bersifat accountable. Kedua, hasil penilaian kinerja dosen dalam pembelajaran perlu dilakukan secara proporsional 
dengan mempertimbangkan ke mana saja laporan hasil penilaian kinerja itu perlu disampaikan agar dampaknya akan memberikan kontribusi yang optimal dalam upaya memperbaiki dan mengembangkan kinerja dosen. Ketiga, penilaian terhadap kinerja dosen dalam penentuan nilai akhirnya perlu mempertimbangkan aspek lainnya seperti kemampuannya dalam pembelajaran.

\section{DAFTAR RUJUKAN}

Akdon. Strategic Management For Educational Management. Bandung: Alfabeta, 2006.

Fandy, Tjiptono. Prinsip-Prinsip Total Quality Service. Yogyakarta: Andi Offset, 2003.

Futwengler Dale. Penilaian Kinerja. Yogyakarta: Andi, 2002.

Hoy, Wayne K Dan Miskel, Cecil G. Educational Administration, Theory, Research, And Practice. New York: McGraw -Hill, 2001.

Robbins, Stephen. Organizational Behavior:Concepts Controversies And Applications. New Jersey: Prentice-Hall, Engelwood Cliffs, 1991.

Simanjuntak J, Payaman. Manajemen Dan Evaluasi Kinerja. Jakarta: Fe Universitas Indonesia, 2005.

Solichin Abdul Wahab. Analisis Kebijaksanaan Dari Formulasi Ke Impelementasi Kebijaksanaan Negara. Jakarta: Bumi Aksara, 1991.

Vincent, Gaspersz. Sistem Manajemen Kinerja Terintegrasi Balances Scorecard Dengan Six Sigma Untuk Organisasi Bisnis Dan Pemerintah. Jakarta: PT. Gramedia, 2006. 